\title{
INTERNATIONAL PERSPECTIVES
}

\section{Knowledge Makers: Indigenous Undergraduate Researchers and Research}

Sereana Naepi, Airini, Thompson Rivers University, Canada

\begin{abstract}
As higher education institutions seek to provide further scope for diversity in their practices, there is space opening up for Indigenous undergraduate research. This article reflects on the Knowledge Makers program, an Indigenous undergraduate research initiative based in British Columbia, Canada. The Knowledge Makers program shows what is possible when an Indigenous approach is used to mentor Indigenous undergraduate students and offers promising practices for increasing Indigenous researchers and research, such as drawing on the knowledge of Indigenous ancestors, valuing Indigenous research methodologies, using a strengths-based approach, performing research as a type of service, and committing to legacy.
\end{abstract}

Keywords: Canada, decolonization, equity, Indigenous peoples, undergraduate research

doi: $10.18833 /$ spur/2/3/7

The potential of the 370 million Indigenous peoples around the world has never been greater. However, research and research institutions continue to reproduce a colonial knowledge system that devalues not only Indigenous knowledge systems but also other knowledge systems that do not reinforce, continue, or empower higher education's monocultural epistemic tradition (Tamdgidi 2012). The colonial mind-set has deemed who can produce knowledge and who cannot (Shilliam 2016), as well as worked "to segregate peoples from their lands, their pasts, their ancestors, spirits and agencies"
(Shilliam 2016, 378). Higher education's historical and continuing research practices are a core threat to indigenization as they continue to marginalize and engage in the epistemological silencing of Indigenous knowledge (Thaman 2009). As a result, Indigenous peoples across the globe have called for research to be reframed in ways that engage with and respect multiple worldviews, particularly Indigenous worldviews (Alfred 2004; Battiste 2013; Denzin, Lincoln, and Smith 2008; Naepi 2015; Smith 2011; Thaman 2003; Wilson 2008). This reframing is essential to the overall project of Indigenous advancement.

Advancements in Indigenous undergraduate research are a key part of this reframing. The intention of advancing Indigenous undergraduate research is to expand the body of Indigenous-led research and to increase the number of Indigenous academics. Although more Indigenous faculty are entering academe in Canada, the analysis by Airini and Naepi (2018) of first-generation learners shows that nonIndigenous peoples complete doctorates at twice the rate of Indigenous peoples (see Table 1).

This inequity shows that something needs to change in Canadian higher education, and a number of institutional bodies have called for better service to Indigenous students and communities. The postsecondary context has an increased focus on Indigenous outcomes. Universities Canada (2017), with its membership of 97 higher education institutions across Canada, has prioritized closing the gap in higher education. The Truth and Reconciliation Commission (TRC) exposed the cumulative impact of more than 100 years of residential schooling endured by 
TABLE 1. Postsecondary Education Outcomes for 100 Indigenous and Non-Indigenous Canadian Students

\begin{tabular}{|l|c|c|}
\hline Canadian postsecondary education indicators & Indigenous students & Non-Indigenous students \\
\hline For every 100 students at university, how many... & & 64 \\
\hline achieve a bachelor's degree & 71 & 19 \\
\hline achieve a master's degree & 13 & 4 \\
\hline achieve a doctorate & 2 & 4 \\
\hline
\end{tabular}

Note: Derived from Airini and Naepi $(2018,76)$.

150,000 Indigenous children. These children experienced the planned elimination by state and church of the spiritual, cultural, and intellectual development provided by their parents. As a result, the TRC (2015) made 94 calls to action, including the closing of educational achievement gaps within one generation. Higher education institutions recognized the need to serve Indigenous communities better to help close these gaps. One way was to intentionally develop Indigenous researchers beginning at the undergraduate level, increasing the number of Indigenous researchers and expanding the practice of Indigenous research methodologies and methods. The Knowledge Makers program to prepare Indigenous undergraduate researchers is part of the commitment of Thompson Rivers University (TRU) to enhance its service to Indigenous communities.

TRU is open to efforts that support the relatively high proportion (11 percent) of its total enrollment that identifies as Indigenous. TRU has a number of initiatives that engage with the TRC's Calls to Action (2015), such as the Coyote Project (a whole-university approach to improving Indigenous student success), Ombaashi (an international and national coordination network for mentoring in Indigenous health and wellness research), and All My Relations (an Indigenous wellness research network). TRU also has two research chairs whose provincial and national mandates are centered on Indigenous health and education (Rod McCormick and Shelly Johnson). The Knowledge Makers program is led by All My Relations, making it possible to connect Indigenous student researchers with the wider Indigenous research community. The traditional institutional barriers to Indigenous programs (Ahenakew and Naepi 2015) were identified and addressed to make this program possible.

This article will discuss the key values and steps in the Knowledge Makers program. It relies on reflections from Knowledge Makers participants and elders throughout. Their quotations can be found in the Knowledge Makers Journal (see Naepi 2016, 2017, 2018). Where possible, specific authors have been cited.

\section{Outline, Knowledge Makers Program}

Based at TRU and funded by its Research and Graduate Studies office, the Knowledge Makers program accepts a maximum of 15 Indigenous students each year from across the university to participate in "making knowledge" through mentored research. Naepi, a coauthor of this article and a cofounder of the Knowledge Makers program, is Indigenous Fijian/Palagi (white/settler) and Airini, the other coauthor and program cofounder, is Samoan/Pakeha (white/settler). Their goal is for the program to be led by an Indigenous person (or persons) from Canada to reflect a full commitment to diversity in academe. To develop a program that would meet the needs of Indigenous undergraduate students at the university, the authors drew on research principles from experience in the Pacific region (see Airini et al. 2010; Health Research Council 2014; Patterson 2018; Naepi forthcoming). The five assumptions that provide the grounding for the Knowledge Makers program are described in Table 2.

Figure 1 provides an outline of the Knowledge Makers program and the steps that must be completed by the students to receive a $\$ 1,000$ award from the TRU Research and Graduate Studies office.

Since its inception three years ago, there have been 42 participants in the Knowledge Makers program. Of these, two have pursued postbaccalaureate study, two have received national graduate scholarships, four have obtained master's degrees, nine have become research assistants, five have received graduate studies scholarships, one has participated in an international internship, one has received mainstream funding for an undergraduate research project, one has started a business informed by Knowledge Makers research, and 42 have published at least one journal article. Participants have self-identified as members of the Secwepemc Nation, Ojibway Nation, Saulteau First Nation, Métis, Seton Lake Band, Shushwap Nation, Dakelh Nation, Stó:lō Nation, Cold Lake First Nations, Waywayseecappo First Nations, Treaty Four Gimley, Ahnishinaabe, Chippewas of Nawash Unceded First Nation, 
TABLE 2. Assumptions and Practices in the Knowledge Makers Program

\begin{tabular}{|c|c|c|}
\hline & Assumption & Practice \\
\hline 1 & We draw upon the knowledge of our ancestry. & $\begin{array}{l}\text { Program participants are encouraged to bring the knowledge of their } \\
\text { ancestors into the research space. }\end{array}$ \\
\hline 2 & $\begin{array}{l}\text { We value Indigenous research methods that expand the } \\
\text { research canon and resist "miraculating" the Indigenous } \\
\text { peoples. }\end{array}$ & $\begin{array}{l}\text { Program participants engage in being critical not only of mainstream } \\
\text { research methods and methodologies but also Indigenous research } \\
\text { methods and methodologies, identifying how particular research } \\
\text { methods and methodologies may not work for their project. They also } \\
\text { are encouraged to consider how current research processes serve or do } \\
\text { not serve Indigenous peoples. }\end{array}$ \\
\hline 3 & We take a strengths-based approach. & $\begin{array}{l}\text { Those involved in the Knowledge Makers program consciously work } \\
\text { against thinking, research design, and words that imply deficits. }\end{array}$ \\
\hline 4 & Our research is a form of service. & $\begin{array}{l}\text { Program participants are encouraged to consider and understand that } \\
\text { action and change are a necessary part of the research } \\
\text { process. }\end{array}$ \\
\hline 5 & We commit to legacy. & $\begin{array}{l}\text { Those involved in the program understand that the Knowledge Makers } \\
\text { program is creating a legacy of Indigenous researchers and that these } \\
\text { researchers need to be able and motivated to undertake quality research } \\
\text { that has a positive effect on Indigenous communities. }\end{array}$ \\
\hline
\end{tabular}

Note: Derived from Naepi and Airini (2018).

St'at'limc Nation, Ts'Kw'laxw First Nation, Tsimshian, Carrier, Mi'kmaq, Nsyixcen: Upper Nicola Band, Tkemlups te Secwepemc, Tlingit, Neskonlith Indian Band, Inuit: Nunatsiavut region, Haida, Tahltan, T'exlc (Williams Lake Band), Tsqescen (Canim Lake), Stella'ten First Nations, Te Tsq'escen, Gitanmaax Band, Nak'azdli and Saik'z First Nation, Dene, Simpcw, Nisga'a, Nak'azdli Whuten, and Skidegate, Haida Gwaii. A key commitment is service to the unceded territory in which TRU is located. For the first time, in 2018, more than 50 percent of Knowledge Makers program participants were from Secwepemcul'ecw, the First Nations peoples who permit the operation of the program in their territory. The 42 participants have come from a range of disciplines at the university, including business, computer science, education, fine arts, humanities, law, nursing, sciences, social sciences, social work, and tourism.

Beyond the quantitative measurements such as publication and research award rates, the Knowledge Makers program also has seen more holistic outcomes. Reading through each year's Knowledge Makers Journal gives insight into the program's impact on students' understanding of the role of their knowledge in research. In 2018, Dundas Oke $(2018,11)$ reflected that Indigenous research meant the following:

generous invitations to learn about self, family, history and community through creative pathways. For myself, I have realized it is at once transformative and continuous. We are asked to carry with us that which is already known to effect transformative change in ourselves, relationships, and communities. We are guided by those who came before to bring light to our unique place in the world.

In the first cohort of the Knowledge Makers program, Scherer $(2006,7)$ reflected that Knowledge Makers had

encouraged me to think of research through the eyes of my people.... consequently, I am able to look at research with a more holistic point of view, and incorporate Indigenous values into my methodology.... I now look at research from a new perspective-one that is closer to who I am, and not based solely on what a specific institution's ideals and expectations are.

The Knowledge Makers program is intentional about creating space for Indigenous undergraduate students to learn about research through an Indigenous lens, with the expectation that they will come to understand research along similar lines to Scherer and Dundas Oke.

\section{Program Steps}

\section{One-on-One Meetings}

One-on-one meetings establish a relationship between the program coordinators and participants. This is an important step in Indigenous research, as personal relationships are key to many Indigenous research methods (Chilisa 2012; Denzin et al. 2008; Kovach 2009; Naepi 2015; Naepi forthcoming; Wilson 2008). The first one-on-one meeting allows each participant to enact assumption 1, we draw upon the knowledge of our ancestry, as the coordinator becomes acquainted with the student and the student's 
FIGURE 1. The Steps in the Knowledge Makers Program

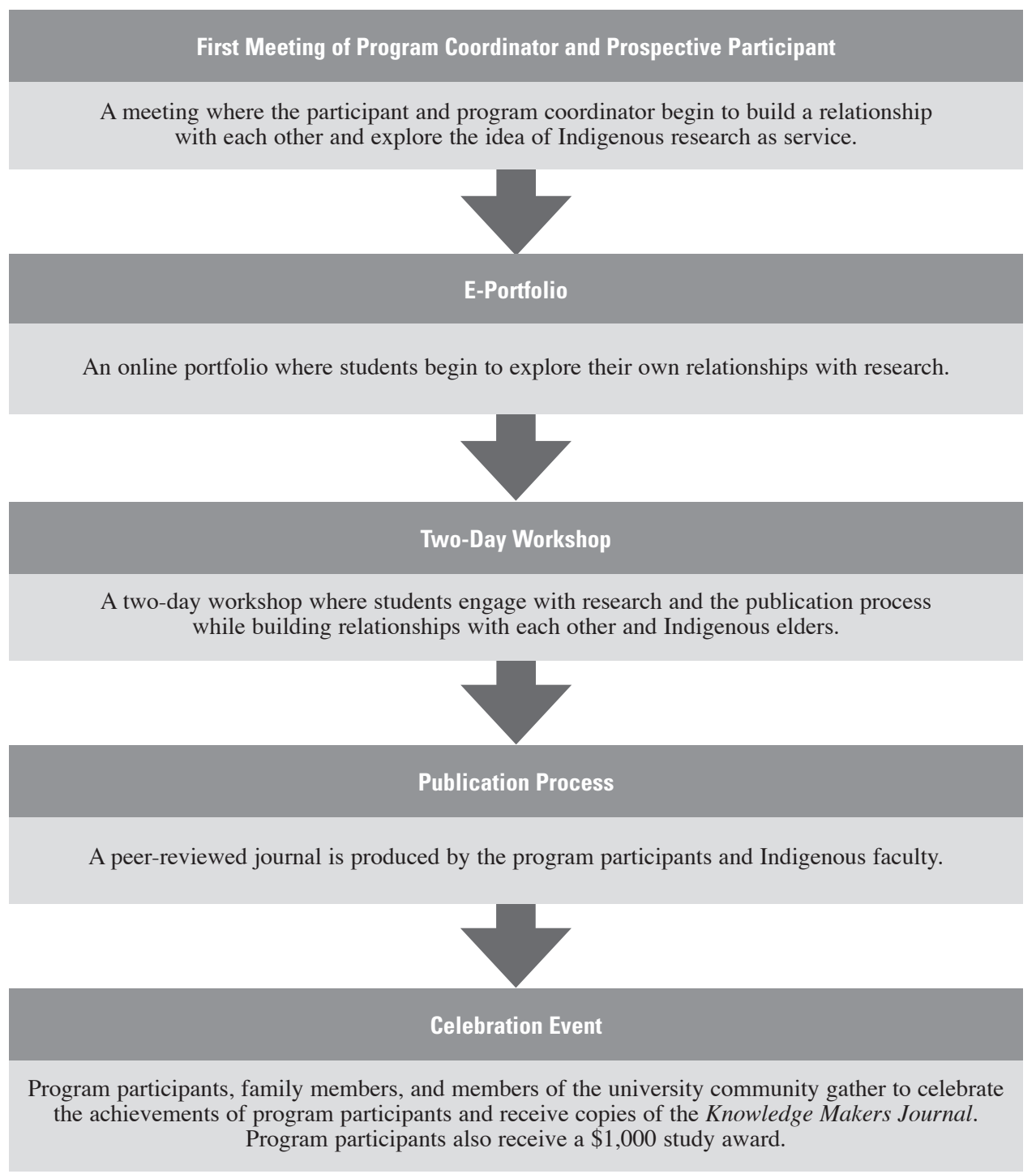

families and communities. At this meeting, the coordinator and the student discuss the process of the Knowledge Makers program and ensure that the participant has the time and energy to commit to the program during a busy time of year. The coordinator and participant discuss a mutual area of interest and how it might be applied to a research project. This meeting is an initial introduction to Indigenous research methodologies, with a heavy emphasis on research as service (assumption 4). The coordinator and participant discuss how the research can be of service to the participant's community and the wider Indigenous community. The aim is to ensure that, in the earliest stages, Knowledge Makers participants have a relationship with the program and its coordinators, understand the level of commitment expected, have a rough idea of what research product they would like to produce, and begin to engage with the idea of research as service.

\section{e-Portfolio}

In 2017, e-portfolios were introduced to the Knowledge Makers program. In the e-portfolio, participants can reflect on their upcoming journey into research and how their experiences contribute to it. Participants are asked to introduce themselves and describe the type of research that they would like to do. This process not only grounds the student in Indigenous practices of introducing themselves through community but also enables coordinators and faculty members to learn more about the students, their communities, and their research before the workshop portion of the program. An example of this is Defont's (2018) e-portfolio:

I am from the Skidegate Band of the Haida Gwaii First Nation, I am of the Eagle Clan, my family name is Brown, and we are represented by the houses of the 
Moon and the Killer Whale. I was born and raised in the inner city of East Vancouver, it is my home. I am a fourth year social work student who believes I can accomplish absolutely anything I set my mind to; I have a laundry list of what I plan to pursue after graduation: I will achieve my $\mathrm{PhD}$, I will teach, I will work front line on the Downtown East Side, I will go into Psychology, I will be a free-range social worker, and so much more.

This practice normalizes assumption 1, that we draw upon the knowledge of our ancestry, so that Knowledge Makers participants know that discussing their background is a crucial component of their writing, their research process, and the workshop portion of the program.

Participants are asked to reflect on someone who inspires them and the values practiced by this person. This step prepares them to talk about research as a set of values; many have experienced research classes in which the process of conducting research is pre-defined, rather than one that reflects the researcher's values. When they are asked to reflect on values they admire, they begin a process of establishing their own set of research values and can identify Indigenous research methodologies that reflect their values. An example of this can be found in the e-portfolio of Mattice (2018):

The chief of Williams Lake Band has inspired me in so many ways. She is dedicated to the people as a leader and advocates for us all when she is needed. At the same time[,] if anything negative comes in her path[,] she will always hold her composure and not let anything offend her. I see this as strength and a great role model for our community. She always is a non-judgmental person and she would say "remember those who are less fortunate than yourself and share with them where ever you can." And with her busy life, I always see that she keeps her family and culture her first priority.

The reflections of Knowledge Maker program participants on their values enacts assumption 1, as it enables them to see how those within their own lives and communities can be a source of inspiration within their research work.

Knowledge Maker program participants also are asked to consider the words of Indigenous researchers. They are provided with a list of quotations about Indigenous researchers from around the world, with a heavy emphasis on Canadian Indigenous scholars, and they have the option to provide their own quotation and explain why those particular words have meaning to them. Wenlock (2018) described the personal impact of Chilisa's quote about culturally responsive methodologies:

"To illustrate culturally responsive methodologies is to acknowledge the local histories, traditions and Indigenous knowledge systems that inform them" (Chilisa 2012, 161).
Dialogues and interactions happen not only between people but more specifically, between people in particular spaces at particular times. Culturally responsible methodologies approach research by recognizing this specificity. In order to pursue knowledge and build relationships situated in time and space, it is necessary to acknowledge and honour the history and traditions of the local Indigenous people. As a nursing student, in pursuit of the knowledge, [I] have [had] many opportunities to build upon my understanding of the local Indigenous histories and traditions, both in class and individually. One of the ways that I have engaged with culturally responsible methodologies was with my nursing class, when we took discussion about racism and indigenous health and well-being, and moved them into traditional Indigenous spaces and into the outdoors. Purposely, we held these conversation[s] in the traditional pit homes of the Secwepemc peoples and at the museum and heritage park in Kamloops. By ... moving the conversation space, it gave nursing students, and myself, an opportunity to engage with the rich history of Indigenous peoples and offered a different lens for understanding health and wellbeing. (emphasis in original)

Increasingly, Knowledge Makers program participants are beginning to provide quotations from their own Indigenous researchers, as seen below:

"The meaning of land is tied to the notion of indigenous use but also to the presence of Aboriginal poetics that anchors people to the land at the deepest level of human meaning, identity and culture" (Elsey 2013, 117). Elsey's quote about the many roles land encompasses perfectly articulates my many experiences, connections, values and goals instrumental to developing the person I am and want to be in the future. My academic goals reflect the multidimensionality land has in my life. The research I pursue will expand the limited purview land has in western methodologies to reflect true Indigenous ways of knowing and being informed by the land. (Munroe 2018, emphasis in original)

The increase in Indigenous research quotations provided by participants may signify that Indigenous research methodologies are now discussed within the participants' classrooms.

This exercise is included in the e-portfolio, as it enables program participants to see that there is a history of Indigenous faculty working on Indigenous research methods and that they are part of a community of Indigenous researchers. This enacts assumption 2, as Knowledge Makers participants are invited to engage with the Indigenous research canon and understand that it is a space where critical dialogue can take place. 


\section{Workshop}

Knowledge Makers program participants attend a two-day workshop in which Indigenous research methodologies are explored in an Indigenous classroom. When participants enter the classroom to make a circle, they adhere to local tradition by saying a prayer and then circling the classroom clockwise, led by the elders, before entering the circle. Once the circle is entered, the focus is on relationship building, reflecting on what is to be undertaken and looking to the elders for guidance. The elders are then asked to present the personalized research portfolios assembled by the program coordinators and based on conversations with each program participant. These portfolios contain one general Indigenous research methodologies article, one article that presents a good example of how to write from an Indigenous perspective, and at least three articles that are linked to either the program participant's prospective research from an Indigenous perspective or written by an individual from their nation or community. These initial actions make clear that the space entered by the program participants is a space of tradition, respect, and ceremony, ensuring that the program participants can connect the act of research to their own community's practices. They see that it is possible to include Indigenous ways of knowing and being within a research space, not just on paper but also in experience.

The next step in the workshop is to describe Indigenous research and its expression as a form of service. This is central to the Knowledge Makers program. When thinking about assumption 5 (commit to legacy), it is important to see that assumption 4 (our research will be a form of service) is a necessary part of the conversation. The research intentions of the program participants are outlined, framing their research goals as service to their own or the wider Indigenous community. For some, this is an easy connection, as seen in Manuel's piece "The Spirituality Bridge Leading Away from Substance Abuse" (2017) that explores the interrelationship of residential schools, substance abuse, and spirituality with very direct measurable outcomes. Others require longer conversations to understand how their work can be of service. This is the case for "Confluence of Knowledge" (Paul 2018), which explores Secwepemc epistemic traditions and their role in increasing understanding of human environmental impact.

An important part of this exercise is that it is done in a circle. Everyone shares intentions and discusses how to be of service. In 2017, a program participant reflected on how this exercise provided a sense of relief, as it made clear that others were going to be working in service to all of the different and urgent areas of Indigenous peoples' lived realities: "There are so many different aspects being covered. Thank goodness you guys are taking care of those things I think about as well. My goodness, there is [sic] all of us in here willing to tackle it. Thank you" (Naepi
$2017,21)$. Woven into these conversations are examples of Indigenous research and their relationship to service, description of project methods, and discussion of participants' intentions vis à vis the projects.

Throughout the two days, program participants learn how to shape a research idea into a publication. At least two students' research ideas are used to show how to respond to the call for papers with either a specific idea or a broad understanding of an area of interest for research. Woven into this exercise is assumption 3, using a strengths-based approach, emphasizing that every idea is worthy of exploration and respecting the level of courage required to have an idea mapped out in the group through a back-and-forth process with the coordinator.

Fredborg's "Multi-Eyed Vision" (2018) is an example of a piece for which a participant had a general idea of how he wanted to be of service and why this was important to him. This general idea was turned into a workable paper in the middle of the circle, illustrating to the program participants that it is possible to take intentions, no matter how well defined, and create a research paper. Fredborg ended up exploring the importance of spirituality in $\mathrm{K}-12$ education to ensuring Indigenous student success.

Throughout the two days of the workshop, Indigenous faculty and staff join the circle and share reasons for the importance of Indigenous research. They share thoughts such as those of Brown, supervisor for aboriginal services at TRU, at the opening of the 2017 Knowledge Makers circle:

When you think about your ancestors and what built your bones and values and you put upon that what you are doing here in education[,] you create a trajectory that is totally unique in this world. You have the ability to make changes. That is honoring the chief in you.

You have permission to be stubborn against systems that humans made, to make your way up this system. Find the words. Be stubborn and do not be bowled over ... We have to work together. Think about our traditional roots, think about traditional knowledge. We have got lots of work to do. (Brown 2017, i)

The inclusion of everyone enables the program participants to see themselves as part of a wider community of Indigenous scholars. The visitors also tend to share advice and thoughts that connect to assumptions 1 (we draw upon the knowledge of our ancestry) and 5 (we commit to legacy). Perhaps in another setting, these visits would be seen as interrupting the pedagogical practice, but within the Knowledge Makers program, they are seen as adding value to the circle.

Elders are understood to be central to the making and actions of the circle. They share their thoughts on student 
projects; engage one-on-one with program participants; and provide prayers, such as at the opening and closing times of the workshop. One program participant explained the significance of the elders' presence during the 2017 workshop: "I don't know how I would get through university without Elders to remind me where I am coming from. Just because I am not learning it in school doesn't mean that it isn't there" (personal communication, Knowledge Maker Workshop participant, 2017).

Elders also have provided reflections on their time spent in the Knowledge Makers program. After the first Knowledge Makers workshop, Elder Mike Arnouse (2016, 78) closed one day with this thought: "Sometimes you find a place and it reminds where you're going. You put a notch in the tree to remind you and your children who follow after you. I thank you all. You have put a notch in my heart to remember."

In 2018, four elders joined the circle, and each of them is highlighted in the 2018 Knowledge Makers Journal with a full-page image from their time within the circle and a piece of their wisdom. Their presence in the workshop reaffirms to the students the importance of their work:

Being part of Knowledge Makers has opened up a huge door that I thought might never happen in my lifetime. I'm just so grateful now that all the knowledge that I have is not going to get lost. I'm so proud of you. (Patrick Moller 2018, 77).

\section{Publication}

The Knowledge Maker program participants receive a formal call for papers for the Knowledge Makers Journal before the workshop portion of the program. Each participant responds to the call with original writing and research. After the workshop, the participants complete a paper and submit it to the journal's editorial board, which consists of Indigenous faculty and administrators such as a Canada research chair, a dean, and early-career faculty. Once the article has been checked for relevance to the call for papers, the editors return feedback from the peer review. The program participant then works on the requested changes either individually or with the coordinator (or another appropriate faculty member) if the changes requested are significant. The article is resubmitted and sent to the copyeditor, who checks for errors and returns it to the authors for appropriate changes. Indigenous faculty also are invited to contribute their reflections on their own research journeys to the journal. The journal consists of not only articles of program participants but also images and quotations from the workshop. The goal is for the publication to serve not only as an academic journal but also as an archive of participant experiences that can inform their research journeys. It is important to adhere to the standard steps to publication during this phase of the program so that the Knowledge Maker program participants are empowered in what can be a daunting process even for the most experienced faculty member.

\section{Indigenous Research Celebration Event}

TRU hosts a Celebrating Indigenous Research evening event each year. Senior administrators from across the university, including the president, attend, and a keynote address is delivered.

The evening begins by recognizing those gathered and recognizing the place of the gathering. The importance of having Indigenous research led by Indigenous researchers is discussed, as are Indigenous strength and potential. Knowledge Maker program participants are invited to the podium to collect their copies of the Knowledge Makers Journal and their $\$ 1,000$ study awards. They acknowledge their friends and family (those in attendance and others) and read from their journal article. Then, in keeping with Indigenous hunting, fishing, and gathering traditions, the program participant gives a copy of the Knowledge Makers Journal to a person special to them, as a way of honoring that person. It is an emotional night, with many tears and smiles as Indigenous undergraduate students - many of whom the first in their families to publish as researchers - announce that they are "knowledge makers."

\section{Discussion}

Indigenous peoples are the original researchers, scientists, philosophers, engineers, and artists. At this time in history, in Canada and elsewhere, there is a need to increase Indigenous research and researchers so that Indigenous peoples can continue to lead knowledge-making and continue to do what they always have done. The potential for Indigenous researchers to lead research by and for Indigenous peoples and communities has never been greater. Since its inception three years ago, 42 participants in the Knowledge Makers program have become part of a wider Indigenous research community and will continue to serve Indigenous communities. What began as an undergraduate initiative now includes three Knowledge Makers Circles-undergraduate, master's, and doctoral.

Beyond the numbers there are significant successes. Knowledge Maker program participants have shared their thoughts about the whole experience reaffirming identity:

Being part of this made me more confident. It affirmed this is my identity. This is who I am. (Naepi 2017, 10, emphasis in original)

For us to sit here today it feels so very powerful. I feel connected to past generations.(Naepi 2016, 33)

They also have shared that it has given them confidence in research: 
This gave me more courage and confidence to explore more research opportunities. (Naepi 2017, 4)

Before I kind of knew my area of interest less so subject area. I think I found it here. (Naepi 2016, 13)

The Knowledge Makers program also gives participants a sense of hope:

Coming here made me think well maybe we can change the face of Canada.... We have a lot to teach the world. (Naepi 2016, 16)

It is exciting to look forward to the future and bringing this experience into my future endeavors. (Naepi 2017, 65)

The Knowledge Makers program is a research initiative that is in service to Indigenous peoples and communities. The program engages Indigenous undergraduate students in research in ways that are familiar and safe for Indigenous peoples, reframing definitions of research, researchers, and research performance. This is research as a form of service, training the next generation of Indigenous researchers and, in so doing, transforming wider research endeavors in positive ways:

[Knowledge Makers] is courage. This is a gift to everyone. (Naepi 2016, 19)

\section{Acknowledgments}

As international Indigenous guests, the authors are aware of the importance of holding space without overtaking it within higher education institutions. The Knowledge Makers program takes place on the traditional and unceded territory of the Secwepemc Nation within Secwepemcul'ecw. The authors are grateful for the generosity of the Secwepemc Nation in hosting the university and its members as guests on their territory and for their support of the Knowledge Makers program. The program also has benefited from the advice of First Nations elders, institutional Indigenous leaders, and Indigenous faculty members.

\section{References}

Ahenakew, Cash, and Sereana Naepi. 2015. "The Difficult Task of Turning Walls into Tables." In Sociocultural Realities: Exploring New Horizons, ed. Angus H. Macfarlane, Sonja Macfarlane, and Melinda Webber, 181-194. Christchurch, NZ: Canterbury University Press.

Airini, Melani Anae, Karlo Mila-Schaff, Eve Coxon, Dion Mara, and Kabini Sanga. 2010. "Teu Le Va: Relationships across Research and Policy in Pasifika Education." Accessed December 29, 2014. http://www.educationcounts.govt.nz/_data/assets/ pdf_file/0009/75897/944_TeuLeVa-30062010.pdf

Airini, and Sereana Naepi. 2018. "A Notch in My Heart: University Practices That Help Canadian First Generation Student Success." In Understanding Experiences of First Generation University Students: Culturally Responsive and Sustaining Methodologies, ed. Amani Bell and Lorri Santamaria, 73-97. London: Bloomsbury. doi: 10.5040/9781350031869.0010
Alfred, Taiaiake. 2004. "Warrior Scholarship: Seeing the University as a Ground of Contention." In Indigenizing the Academy: Transforming Scholarship and Empowering Communities, ed. Devon Mihesuah and Angela Wilson, 88-99. Lincoln: University of Nebraska Press.

Arnouse, Mike. 2016. Untitled. In Naepi 2016, 89.

Battiste, Marie. 2013. Decolonizing Education: Nourishing the Learning Spirit. Saskatoon, Canada: Purich.

Brown, Joanne. 2017. Untitled. In Naepi 2017, i.

Chilisa, Bagele. 2012. Indigenous Research Methodologies. Thousand Oaks, CA: Sage.

Defont, Roxie. 2018. "Knowledge Maker.” Accessed February 27, 2018. https://roxiedefontkm.trubox.ca/about-gunsis-eportfolio

Denzin, Norman K., Yvonna Lincoln, and Linda T Smith. 2008. Handbook of Critical and Indigenous Methodologies. Los Angeles: Sage. doi: 10.4135/9781483385686

Dundas Oke, Emily. 2018. "Contemporary Art as Epistemology: Land/Bodies/History." In Naepi 2018, 11-16.

Elsey, Christine J. 2013. The Poetics of Land and Identity among the Indigenous Peoples of British Columbia. Winnipeg: Fernwood.

Fredborg, Aaron. 2018. "Multi-Eyed Vision.” In Naepi 2018, 6-10.

Health Research Council. 2014. Health Research Council Pacific Guidelines. Accessed December 29, 2017. http://www.hrc.govt. $\mathrm{nz} /$ sites/default/files/Pacific\%20Health\%20Research\%20Guidelines\%202014.pdf

Kovach, Margaret. 2009. Indigenous Methodologies: Characteristics, Conversations, and Contexts. Toronto: University of Toronto Press.

Manuel, Rhea. 2017. "The Spirituality Bridge Leading Away from Substance Abuse." In Naepi 2017, 62-65.

Mattice, Jacqueline. 2018. "Inspiration and Teachings." Accessed February 27, 2018. https://jacquelinematticekm.trubox.ca

Munroe, Annie. 2018. "Indigenous Researchers.” Accessed February 27,2018 . https://anniemunroekm.trubox.ca

Naepi, Sereana. 2015. "Navigating the Currents of Kaupapa Māori and Pan-Pacific Research Methodologies in Aotearoa, New Zealand.” MAI Journal 4: 71-84.

Naepi, Sereana (Ed.). 2016. Knowledge Makers Journal 1. Kamloops, Canada: Thompson Rivers University. https://knowledgemakers.trubox.ca/knowledge-makers-journal/2016-2/

Naepi, Sereana (Ed.). 2017. Knowledge Makers Journal 2. Kamloops, Canada: Thompson Rivers University. https://knowledgemakers.trubox.ca/knowledge-makers-journal/2017-2/

Naepi, Sereana (Ed.). 2018. Knowledge Makers Journal 3. Kamloops, Canada: Thompson Rivers University. https://knowledgemakers.trubox.ca/knowledge-makers-journal/2018-2/ 
Naepi, Sereana. Forthcoming. "Pacific Research Methods in Education." In Oxford Encyclopedia of Qualitative Research Methods in Education. Oxford: Oxford University Press.

Naepi, Sereana, and Airini. 2018. "Be the Real Me: Learning from Knowledge Makers.” In Naepi 2018, 58-62.

Patrick Moller, Estella. 2018. Untitled. In Naepi 2018, 77.

Patterson, Sereana Elina. 2018. "Beyond the Dusky Maiden: Pasifika Women's Experiences Working in Higher Education." $\mathrm{PhD}$ diss., University of British Columbia.

Paul, Lyle. 2018. “Confluence of Knowledge.” In Naepi 2018, $51-55$.

Scherer, Marcus. 2016. "The Importance of Research and the Value of Knowledge Makers.” In Naepi 2016, 6-7.

Shilliam, Robbie. 2016. "On Africa in Oceania: Thinking besides the Subaltern." Theory, Culture \& Society 33(7/8): 374-381. doi: $10.1177 / 0263276416676346$

Smith, Linda. 2011. "Kaupapa Māori Research.” In Reclaiming Indigenous Voice and Vision, ed. Marie Battiste, 225-247. Vancouver, Canada: UBC Press.

Tamdgidi, Mohammad. 2012. "Editor's Note: To Be of but Not in the University." Human Architecture: Journal of the Sociology of Self-Knowledge 10(1).

Thaman, Konai, H. 2003. "Decolonizing Pacific Studies: Indigenous Perspectives, Knowledge, and Wisdom in Higher Education." Contemporary Pacific 15: 1-17. doi: 10.1353/cp.2003.0032

Thaman, Konai H. 2009. "Towards Cultural Democracy in Teaching and Learning with Specific References to Pacific Island Nations (PINs)." International Journal for the Scholarship of Teaching and Learning 3(2): art. 6. doi: 10.20429/ijsotl.2009.030206
Truth and Reconciliation Commission of Canada. 2015. Foundational Document: Calls to Action. Accessed August 19, 2018. doi: 10.5663/aps.v5i1.25647

Universities Canada. 2017. "Indigenous Student Education." Accessed November 17, 2017. https://www.univcan.ca/priorities/ indigenous-education

Wenlock, Jayne. 2018. "Indigenous Researchers.” Accessed February 27, 2018. https://jaynewenlockkm.trubox.ca/indigenousresearchers

Wilson, Shawn. 2008. Research Is Ceremony: Indigenous Research Methods. Black Point, Canada: Fernwood.

\section{Sereana Naepi}

Thompson Rivers University, sepatterson@tru.ca

Sereana Naepi is the associate director of All My Relations: An Indigenous Wellness Research Network at Thompson Rivers University. Naepi completed her PhD at the University of British Columbia and conducts research into how higher education institutions can be more inclusive of all faculty, staff, and students through significant structural change. She has more than a decade of experience supporting Indigenous learners in higher education in Aotearoa, New Zealand, and Canada.

Airini is the dean of education and social work at Thompson Rivers University and adjunct professor in Te Ara Poutama at Auckland University of Technology, Aotearoa, New Zealand. Her current research focuses on designing twenty-first-century systems to close gaps in education success and lift social outcomes. Airini specializes in equity in higher education. 